\title{
Monte Carlo calculations for reporting patient organ doses from interventional radiology
}

\author{
Wanli Huo ${ }^{1}$, Mang Feng ${ }^{1}$, Yifei $\mathrm{Pi}^{1}$, Zhi Chen ${ }^{1}$, Yiming Gao ${ }^{2}$, X. George Xu ${ }^{1,2 *}$ \\ ${ }^{1}$ University of Science and Technology of China, Hefei, China \\ ${ }^{2}$ Rensselaer Polytechnic Institute, Troy, New York, USA
}

\begin{abstract}
This paper describes a project to generate organ dose data for the purposes of extending VirtualDose software from CT imaging to interventional radiology (IR) applications. A library of 23 mesh-based anthropometric patient phantoms were involved in Monte Carlo simulations for database calculations. Organ doses and effective doses of IR procedures with specific beam projection, filed of view (FOV) and beam quality for all parts of body were obtained. Comparing organ doses for different beam qualities, beam projections, patients' ages and patient's body mass indexes (BMls) which generated by VirtualDose-IR, significant discrepancies were observed. For relatively long time exposure, IR doses depend on beam quality, beam direction and patient size. Therefore, VirtualDose$\mathrm{IR}$, which is based on the latest anatomically realistic patient phantoms, can generate accurate doses for IR treatment. It is suitable to apply this software in clinical IR dose management as an effective tool to estimate patient doses and optimize IR treatment plans.
\end{abstract}

\section{INTRODUCTION}

VirtualDose is a cloud-based software tool for assessing and reporting patient organ doses from radiological imaging procedures ${ }^{[1-7]}$. VirtualDose was designed to improve the patient dose estimation with considering the latest ICRP (International Commission on Radiological Protection) tissue weighting factors, several validated $\mathrm{CT}$ scanner models, scanner-specific correction factors, and a family of anatomically realistic phantoms which include female and male adults, children with different ages, pregnant females at different gestational stages and obese people of different body weights ${ }^{[8-13]}$. The first application-specific module for patients undergoing CT examinations, VirtualDose-CT, was released in 2013 and is currently used by hundreds of medical physicists and radiologists. This paper describes a project to generate organ dose data for a new application interventional radiology (IR). The database generated from this study will be used in VirtualDose-IR which is designed for reporting patient organ doses and effective dose during an interventional radiology (IR).

IR has been used for treatment and diagnose purposes since 1960s and the number of procedures has grown rapidly recently. According to NCRP (national council on radiation protection) Report No. 160 the exposure to ionizing radiation of the U.S. population has nearly doubled over the past two decades ${ }^{[14]}$. More than 17 million IR procedures were performed in the U.S. in 2006 and these figures will continue to grow ${ }^{[15]}$. Although often clinically justified, the radiation doses from X-ray examinations contribute significantly to the total radiation exposure. The NCRP stated that IR contributed $14 \%$ of the total yearly radiation exposure from medical imaging ${ }^{[15]}$ In complicated IR procedures, patients are exposed to high radiation doses up to $0.5 \mathrm{~Gy}$ to some organs, causing a real concern for radiation injury ${ }^{[16]}$. In order to avoid the deterministic effect and mitigate the risk of unnecessary radiation exposure, it is necessary to assess and report organ doses from these medical procedures.

Estimating organ doses for patients undergoing IR can be done using either experimental measurements or computational simulations. Experimental measurements can be done using dosimeters embedded in a physical phantom. This method is time-consuming and costly, often suffering from the lack of precision in dosimeter reading $[17,18]$. For IR procedures, several studies have been performed to calculate organ doses and effective doses based on $\mathrm{P}_{\mathrm{ak}}$ (air kerma-area product) and precalculated conversion factors. Some researchers employed the

\footnotetext{
a Corresponding author: xug2@rpi.edu
} 
relationship between dose and source-to-surface distance (SSD) in IR to calculate peak skin doses (PSD) and skin dose maps ${ }^{[19-21]}$. Chugh et al and Khodadadegan et al used stylized phantoms and SSD relationship to calculate the skin dose of patients ${ }^{[19,20]}$. Johnson et al employed some more anthropomorphic patient-dependent phantoms and SSD relationship to calculate PSD for patients ${ }^{[21]}$. These methods can only be used to calculate skin doses, but not internal organ doses.

The computational method, on the other hand, takes advantage of advanced Monte Carlo simulation methods and anatomically accurate models of the patients, thus showing a number of advantages in medical physics applications. Several groups used Monte Carlo methods to simulate the patient doses under IR procedures ${ }^{[22-24]}$. FAX06 and MAX06 phantoms were applied by Kramer et al to calculate organ doses for the most common examinations in X-ray diagnosis ${ }^{[22]}$. Bozkurt and Bor used VIP-Man to simulate the organ doses in an interventional cardiological procedure ${ }^{[23]}$. Garzón et al employed Monte Carlo code with FASH and MASH phantoms to stimulate the organ doses of patients undergoing hepatic chemoembolization procedures ${ }^{[24]}$. Those studies used only a few phantoms and cannot represent patient population accurately.

Radiation-induced organ injuries are correlated with the absorbed doses to organs and tissues. The absorbed dose for a specific organ is related to the radiation type, radiation energy, shielding between organ and radiation source. To quantify the whole-body radiation-induced health effects, the effective dose, a radiation protection quantity which is the sum of each absorbed organ dose multiplied with its specific tissue weighting factor, is recommended by ICRP ${ }^{[25]}$.

The positions of irradiation area, patient's body mass indexes and ages for adolescent patients can affect the effective doses and specific organ doses significantly since the tissue thicknesses between source and organs changed dramatically with these parameters. Even the radiation type and the mean absorbed dose for whole body are the same, effective dose varies with irradiation position. While IR procedures can be operated at any parts of the body, previous researches only studied a few body part IR operations. There is no previous study about organ doses for IR operations of all part of body.

To address the needs for the development of a user friendly software tool, a comprehensive organ database deriving from extensive Monte Carlo simulations was established using a set of 23 anatomically realistic patient phantoms including adults, children at different ages, pregnant females at different gestational stages, and obese patients with different body mass indexes (BMIs). We adopted various X-ray energies, absorbers, beam projections, field of views and all parts of the body irradiated in this study, considering most potential IR procedures at all potential parts of the body. This paper describes the calculations and analyses of preliminary data.

\subsection{A Set of 23 phantoms}

Computational human phantoms play a vital role in the field of medical physics patient dose simulations. It can be divided into three generations during its development: the stylized phantoms are combined with simple geometric elements such as cuboids, cylinders spheres and cones; the voxelized phantoms are constructed by massive of tiny voxels representing anatomical structures; the latest generation computational phantoms are the mesh-based phantoms, which are consisted of Non-Uniform Rational B-Splines (NURBs) or polygonal mesh ${ }^{[26-31]}$. Mesh-based phantoms have powerful abilities of great geometrical deformation and shape adjustment. These advantages make it suitable to change outside geometry and inside organ shape and to develop a series of phantoms with realistic anatomical structures from single mesh-based phantom.

A total of 23 whole-body phantoms were used in this project, including children, male and female adults, obese people and pregnant females in a joint effort by Rensselaer Polytechnic Institute (RPI) and the University of Science and Technology of China (USTC). The group of agedependent Chinese adults and adolescences phantoms include males and females with age of new born, 5-year, 10-year, 15-year and adult (named USTC-Adult-Male and USTC-Adult-Female) ${ }^{[32-34]}$, all the anatomical parameters adjusted to agree within $0.5 \%$ with the reference people data of China ${ }^{[35]}$. Other phantoms include pregnant females at 3-month, 6-month and 9-month gestational stages developed from a 30 -week pregnant woman CT imaging ${ }^{[27]}$, reference male and female adults according to ICRP 89 report (named RPI-Adult-Male (RPI-AM) and RPI-Adult-Female (RPI-AF)) ${ }^{[26]}$, a set of obese males and females with body sizes from normal weight to morbidly obese ${ }^{[30]}$.

The geometries for different type of phantoms are displayed in Figure 1. Those phantoms were originally developed using triangular surface meshes, and were converted to voxel-based phantoms by an in-house voxelization algorithm for the purpose of Monte Carlo dose calculations. In order to calculate PSDs accurately, we defined a $2.5 \mathrm{~mm}$-thick layer of air in front of the phantoms and divided it into cubes, each having a $2.5 \mathrm{~mm}$ side length to calculate $\mathrm{Hp}_{(0.07)}$. The arms of phantoms were removed when the simulated patients' arms are raised to the overhead position in lateral beam projections ${ }^{[11]}$.

\section{METHODS}




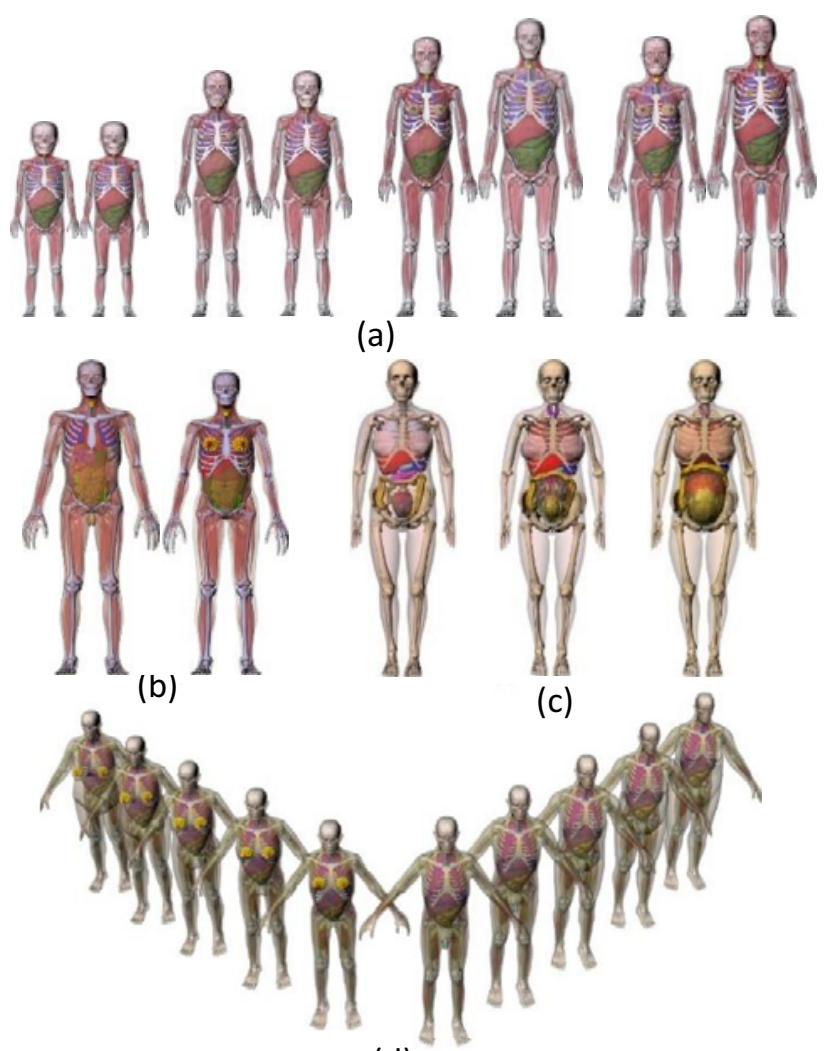

(d)

Figure 1. Phantoms in VirtualDose-IR: (a) adolescent and adult phantoms (from left to right: $5,10,15$, and adult females and males) which are based on Chinese reference standards; (b) Adult male (RPI-AM) and female (RPI-AF) based on ICRP-89 report; (c) Pregnant females at three different gestational stages (3, 6, 9 month); (d) Obese patients in different obesity categories

\subsection{VirtualDose Architecture}

VirtualDose-IR was designed as a SaaS (Software as a Service) application which hosted all its associated data and up-to-date resources centrally on a remote computer server and allow multiple users to access the software functions at the same time via Internet. To implement this architecture, a "Service-Orientated Architecture (SOA)" design was adopted, as shown in figure 2. Programming languages, including Hypertext Markup Language (HTML), Cascading Style Sheets (CSS) and JavaScript, were used to provide an interactive graphical user interface (GUI). For the server-side scripting, C\# was used as the primary programming language.

The completed VirtualDose-IR contains the clientside and server-side interfaces. The client-side interface consists of parameter selection panel, a patient model display, and a dose result display. These allow users to specify the operating conditions of a particular IR treatment for a particular patient.

The server-side interface stores data of 23 different phantoms and their organ doses and effective doses with various IR procedures produced by Monte Carlo simulations. Based on the user-specified IR parameters, VirtualDose-IR fetches and calculates the patient-specific organ dose and effective dose data from the remote server- side database. The results are displayed with a table and a figure on user's browser.

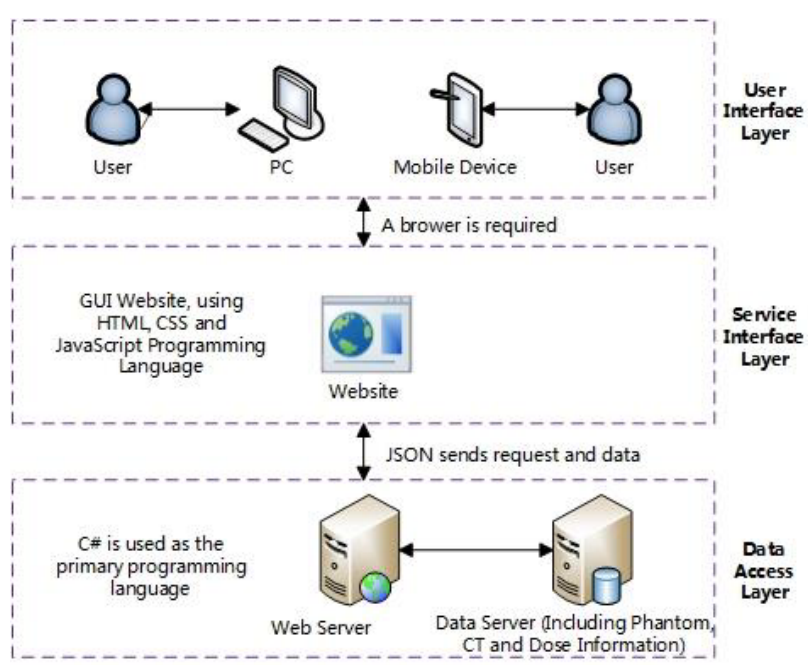

Figure 2. Schematic diagram of the SOA architecture for VirtualDose-IR

\subsection{The Monte Carlo simulations}

The Monte Carlo method is a well-established technique as well as the most accurate way to calculate radiation dose for medical physics applications. In this research, the software MCNPX (Monte Carlo N-Particle eXtended) version 2.7.0 was used for Monte Carlo simulations [36]. This production code designed at the Los Alamos National Laboratory (LANL) can handle the transportation and interaction of photons, electrons, neutrons, protons and heavy ions for complex three-dimensional geometries in a wide range of energies. Coupled with anatomical realistic computational patient phantoms, a Monte Carlo radiation simulation can produce a detailed distribution of radiation dose across various organs and tissues.

A $2.15 \mathrm{~mm}$ thick $\mathrm{Al}$ bed represents the operating bed in these simulations with the consideration of attenuation of the bed. Patient lays on his back at the bed and X-ray irradiated the patient from specific position with certain direction in each simulation. In order to report organ doses, each phantom was deconstructed into several parts. For each part, a series of IR exposure procedures were simulated using the specific tube voltage, tube current, absorber, field of view (FOV) and beam projection in the MCNPX code ${ }^{[37-38]}$. An air ball with constant distance to source was placed above the source as the detector to calculate the air kerma in the center of field in each simulation. Organ doses and effective doses of certain parts of body corresponding to a specific IR protocol were derived from integrating data.

In this research, several different IR exposure situations were studied, the following aspects were considered.

- Beam projections:

posterior anterior (PA), left anterior oblique, $45^{\circ}$ (LAO), right anterior oblique, $45^{\circ}$ (RAO), left lateral (LLAT), right lateral (RLAT) and cranial, $45^{\circ}$ (CRAN).

- Field of views (FOV): 
$40 \mathrm{~cm} \times 40 \mathrm{~cm}, 30 \mathrm{~cm} \times 30 \mathrm{~cm}, 20 \mathrm{~cm} \times 20 \mathrm{~cm}, 10 \mathrm{~cm}$ $\times 10 \mathrm{~cm}$.

- Tube voltages:

$55 \mathrm{kVp}, 60 \mathrm{kVp}, 70 \mathrm{kVp}, 80 \mathrm{kVp}, 90 \mathrm{kVp}, 100 \mathrm{kVp}$, $110 \mathrm{kVp}, 120 \mathrm{kVp}$.

- Filtrations:

$3.5 \mathrm{~mm} \mathrm{Al}+0 \mathrm{~mm} \mathrm{Cu}, 3.5 \mathrm{~mm} \mathrm{Al}+0.1 \mathrm{~mm} \mathrm{Cu}, 3.5$ $\mathrm{mm} \mathrm{Al}+0.2 \mathrm{~mm} \mathrm{Cu}, 3.5 \mathrm{~mm} \mathrm{Al}+0.3 \mathrm{~mm} \mathrm{Cu}$.

The geometries of those projections are shown in figure 3 .
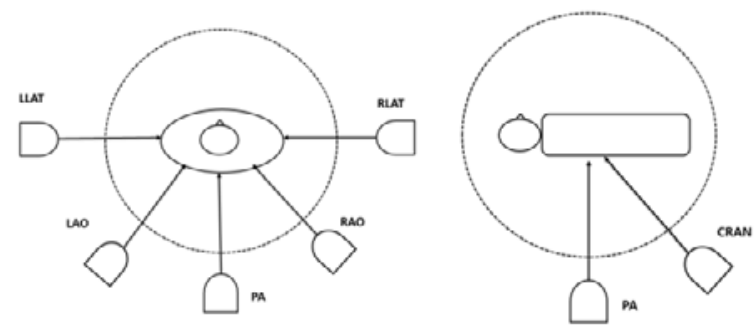

Figure 3. The diagrammatic sketch of beam projections

Considering different patient phantoms with different body sizes, we used different tube voltages and filtrations for every single phantom. While different parts of the body with different thicknesses, the body have been divided into three major sections: head, body and legs, as shown in the figure 4. Each section has different tissue structures and different body thicknesses, but for all the parts of body in every section, the body thicknesses are similar. For each body section of each phantom, the tube voltages and filtrations employed in IR simulations were the same. The voltages and filtrations employed in this study are summarized in table 1 . The ranges of tube voltage and filtration change with body thicknesses according to the relation between body thickness and X-ray quality from AAPM (The American Association of Physicists in Medicine) 125 report ${ }^{[39]}$.

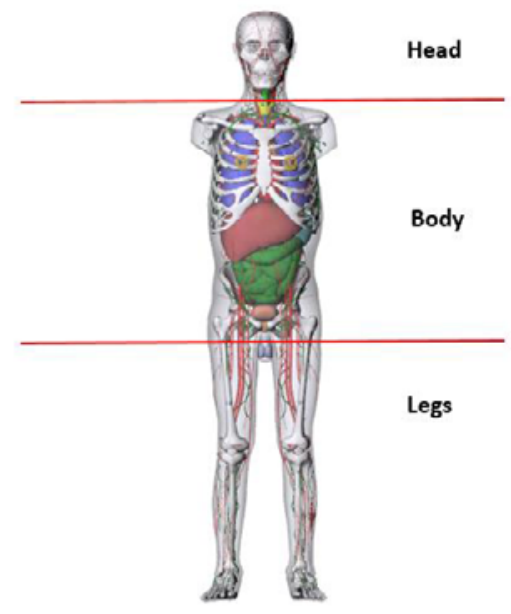

Figure 4. Scheme of dividing patient phantom into three sections: head, body and legs

A conversion factor (CF) was used to convert the Monte Carlo simulation result to absorbed dose per unit integrated tube current in the units of $\mathrm{mGy} / 100 \mathrm{mAs}$. These CFs were unique to each combination of tube voltage and absorber thickness. The CF can be obtained according to equation (1).

$$
\mathrm{CF}=\frac{\text { Kerma }_{\text {in-air }}^{\text {Measured }}}{\text { Kerma }_{\text {Sim-air }}^{\text {Simuled }}}
$$

Where $\mathrm{Kerma}_{\text {in-air }}^{\text {Measured }}$ is the measured kerma value in air in the units of $\mathrm{mGy} / 100 \mathrm{mAs}$ by applying the ionization chamber $44 \mathrm{~cm}$ above the source in air at center of the field; Kerma innulated is the corresponding air kerma value in the units of $\mathrm{MeV} / \mathrm{gram}$-source particle obtained by simulating the ionization chamber in the MCNPX code under the same condition. The units of $\mathrm{CF}$ is (mGy'gram·source paticle)/ (MeV·mAs).

The simulated results from the MCNPX code can be easily converted to absorbed doses by employing these CFs according to equation (2).

$$
\mathrm{D}_{\text {absorbed }}=\mathrm{D}_{\text {simulated }} \times \mathrm{CF} \times(\text { Total } \mathrm{mAs} / 100)
$$

Where $\mathrm{D}_{\text {absorbed }}$ is the absorbed dose in unit of $\mathrm{mGy}$, $\mathrm{D}_{\text {simulated }}$ is the MCNPX simulation result in the units of $\mathrm{MeV} /$ (gram· source particle).

The effective dose was used to evaluate the whole body radiation damage during an IR procedure in this paper. The effective dose can be calculated by using organ doses and organ's tissue weighting factor accounting for equation (3)

$$
E=\sum_{T} w_{T} \sum_{R} w_{R} D_{T, R}
$$

where $\mathrm{D}_{\mathrm{T}, \mathrm{R}}$ is the absorbed dose in tissue $\mathrm{T}$ for radiation type. $\mathrm{W}_{\mathrm{R}}$ is the radiation weighting factor accounting for the relative biological damage of radiation type. $\mathrm{w}_{\mathrm{T}}$ is the tissue weighting factor for specific tissue according to tissue's relative radio sensitivity. The tissue weighting factors used in this paper are derived from ICRP 103 report.

The radiation doses of 23 different patient phantoms undergoing IR procedures with various X-ray quantities, beam projections and all the potential parts of body were calculated in this study. These data will be converted to organ absorbed doses and effective doses and integrated into a database. In VirtualDose-IR, all the detailed distributions of radiation doses of different organs/tissues for a specific type of patient during an IR operation were derived from this large organ dose database.

\section{Results}

\subsection{Comparison of organ dose data for different beam qualities}

To illustrate how the software tool can be used, here we simulate a series of liver IR treatments for adult male patients with the same imaging parameters except for the tube voltages and absorbers. The beam projections and FOVs involving in those simulations are PA and $40 \mathrm{~cm} \times 40$ $\mathrm{cm}$. The results are plotted in figure 5 . Six pairs of beam qualities $(70 \mathrm{kVp}+0.1 \mathrm{~mm} \mathrm{Cu}, 70 \mathrm{kVp}+0.2 \mathrm{~mm} \mathrm{Cu}, 80$ $\mathrm{kVp}+0.1 \mathrm{~mm} \mathrm{Cu}, 80 \mathrm{kVp}+0.2 \mathrm{~mm} \mathrm{Cu}, 90 \mathrm{kVp}+0.1 \mathrm{~mm}$ $\mathrm{Cu}$ and $90 \mathrm{kVp}+0.2 \mathrm{~mm} \mathrm{Cu}$ ) with a constant $3.5 \mathrm{~mm} \mathrm{Al}$ absorber were considered to generate those data for the comparison. As shown in figure 5 organ dose values increase as the tube voltages increase and decrease with the thickness of absorbers increases. The doses for $90 \mathrm{kVp}$ 
Table 1. Summary of tube voltages and filtrations used in IR Monte Carlo simulations for different body sections of type of patient phantom

\begin{tabular}{|c|c|c|c|c|c|c|}
\hline & \multicolumn{6}{|c|}{ Body Sections } \\
\hline & \multicolumn{2}{|c|}{ Head } & \multicolumn{2}{|c|}{ Body } & \multicolumn{2}{|c|}{ Legs } \\
\hline & $\begin{array}{c}\text { tube } \\
\text { voltages } \\
(\mathbf{k V p}) \\
\end{array}$ & $\begin{array}{c}\text { Filtrations } \\
(\mathrm{mm})\end{array}$ & $\begin{array}{c}\text { tube } \\
\text { voltages } \\
(\mathbf{k V p}) \\
\end{array}$ & $\begin{array}{c}\text { Filtrations } \\
(\mathbf{m m})\end{array}$ & $\begin{array}{c}\text { tube } \\
\text { voltages } \\
(\mathbf{k V p}) \\
\end{array}$ & $\begin{array}{c}\text { Filtrations } \\
\text { (mm) }\end{array}$ \\
\hline \multicolumn{7}{|l|}{ Adolescences } \\
\hline 5 year male & $60,70,80$ & $\begin{array}{c}3.5 \mathrm{Al}+0.2 \\
\mathrm{Cu} / 0.3 \mathrm{Cu}\end{array}$ & $60,70,80$ & $\begin{array}{c}3.5 \mathrm{Al}+0.2 \\
\mathrm{Cu} / 0.3 \mathrm{Cu}\end{array}$ & $55,60,70$ & $\begin{array}{c}3.5 \mathrm{Al}+0.2 \\
\mathrm{Cu} / 0.3 \mathrm{Cu}\end{array}$ \\
\hline 5 year female & $60,70,80$ & $\begin{array}{c}3.5 \mathrm{Al}+0.2 \\
\mathrm{Cu} / 0.3 \mathrm{Cu}\end{array}$ & $60,70,80$ & $\begin{array}{c}3.5 \mathrm{Al}+0.2 \\
\mathrm{Cu} / 0.3 \mathrm{Cu}\end{array}$ & $55,60,70$ & $\begin{array}{c}3.5 \mathrm{Al}+0.2 \\
\mathrm{Cu} / 0.3 \mathrm{Cu}\end{array}$ \\
\hline 10 year male & $60,70,80$ & $\begin{array}{c}3.5 \mathrm{Al}+0.2 \\
\mathrm{Cu} / 0.3 \mathrm{Cu}\end{array}$ & $60,70,80$ & $\begin{array}{c}3.5 \mathrm{Al}+0.2 \\
\mathrm{Cu} / 0.3 \mathrm{Cu}\end{array}$ & & $\begin{array}{c}3.5 \mathrm{Al}+0.2 \\
\mathrm{Cu} / 0.3 \mathrm{Cu}\end{array}$ \\
\hline 10 year female & $60,70,80$ & $\begin{array}{c}3.5 \mathrm{Al}+0.2 \\
\mathrm{Cu} / 0.3 \mathrm{Cu}\end{array}$ & $60,70,80$ & $\begin{array}{c}3.5 \mathrm{Al}+0.2 \\
\mathrm{Cu} / 0.3 \mathrm{Cu}\end{array}$ & & $\begin{array}{c}3.5 \mathrm{Al}+0.2 \\
\mathrm{Cu} / 0.3 \mathrm{Cu}\end{array}$ \\
\hline 15 year male & $70,80,90$ & $\begin{array}{c}3.5 \mathrm{Al}+0.1 \\
\mathrm{Cu} / 0.2 \mathrm{Cu}\end{array}$ & $70,80,90$ & $\begin{array}{c}3.5 \mathrm{Al}+0.1 \\
\mathrm{Cu} / 0.2 \mathrm{Cu}\end{array}$ & $60,70,80$ & $\begin{array}{c}3.5 \mathrm{Al}+0.2 \\
\mathrm{Cu} / 0.3 \mathrm{Cu}\end{array}$ \\
\hline 15 year female & $70,80,90$ & $\begin{array}{c}3.5 \mathrm{Al}+0.1 \\
\mathrm{Cu} / 0.2 \mathrm{Cu}\end{array}$ & $70,80,90$ & $\begin{array}{c}3.5 \mathrm{Al}+0.1 \\
\mathrm{Cu} / 0.2 \mathrm{Cu}\end{array}$ & $60,70,80$ & $\begin{array}{c}3.5 \mathrm{Al}+0.2 \\
\mathrm{Cu} / 0.3 \mathrm{Cu} \\
\end{array}$ \\
\hline \multicolumn{7}{|l|}{ Pregnant females } \\
\hline 3 month pregnant & $70,80,90$ & $\begin{array}{c}3.5 \mathrm{Al}+0.1 \\
\mathrm{Cu} / 0.2 \mathrm{Cu}\end{array}$ & $70,80,90$ & $\begin{array}{c}3.5 \mathrm{Al}+0.1 \\
\mathrm{Cu} / 0.2 \mathrm{Cu}\end{array}$ & $60,70,80$ & $\begin{array}{c}3.5 \mathrm{Al}+0.2 \\
\mathrm{Cu} / 0.3 \mathrm{Cu}\end{array}$ \\
\hline 6 month pregnant & $70,80,90$ & $\begin{array}{c}3.5 \mathrm{Al}+0.1 \\
\mathrm{Cu} / 0.2 \mathrm{Cu}\end{array}$ & $70,80,90$ & $\begin{array}{c}3.5 \mathrm{Al}+0.1 \\
\mathrm{Cu} / 0.2 \mathrm{Cu}\end{array}$ & $60,70,80$ & $\begin{array}{c}3.5 \mathrm{Al}+0.2 \\
\mathrm{Cu} / 0.3 \mathrm{Cu}\end{array}$ \\
\hline 9 month pregnant & $70,80,90$ & $\begin{array}{c}3.5 \mathrm{Al}+0.1 \\
\mathrm{Cu} / 0.2 \mathrm{Cu} \\
\end{array}$ & $70,80,90$ & $\begin{array}{c}3.5 \mathrm{Al}+0.1 \\
\mathrm{Cu} / 0.2 \mathrm{Cu}\end{array}$ & $60,70,80$ & $\begin{array}{c}3.5 \mathrm{Al}+0.2 \\
\mathrm{Cu} / 0.3 \mathrm{Cu} \\
\end{array}$ \\
\hline \multicolumn{7}{|l|}{ Average adults } \\
\hline USTC-Adult-Male & $70,80,90$ & $\begin{array}{c}3.5 \mathrm{Al}+0.1 \\
\mathrm{Cu} / 0.2 \mathrm{Cu}\end{array}$ & $70,80,90$ & $\begin{array}{c}3.5 \mathrm{Al}+0.1 \\
\mathrm{Cu} / 0.2 \mathrm{Cu}\end{array}$ & $60,70,80$ & $\begin{array}{c}3.5 \mathrm{Al}+0.2 \\
\mathrm{Cu} / 0.3 \mathrm{Cu}\end{array}$ \\
\hline $\begin{array}{l}\text { USTC-Adult- } \\
\text { Female }\end{array}$ & $70,80,90$ & $\begin{array}{c}3.5 \mathrm{Al}+0.1 \\
\mathrm{Cu} / 0.2 \mathrm{Cu}\end{array}$ & $70,80,90$ & $\begin{array}{c}3.5 \mathrm{Al}+0.1 \\
\mathrm{Cu} / 0.2 \mathrm{Cu}\end{array}$ & $60,70,80$ & $\begin{array}{c}3.5 \mathrm{Al}+0.2 \\
\mathrm{Cu} / 0.3 \mathrm{Cu}\end{array}$ \\
\hline RPI-AM & $70,80,90$ & $\begin{array}{c}3.5 \mathrm{Al}+0.1 \\
\mathrm{Cu} / 0.2 \mathrm{Cu}\end{array}$ & $70,80,90$ & $\begin{array}{c}3.5 \mathrm{Al}+0.1 \\
\mathrm{Cu} / 0.2 \mathrm{Cu}\end{array}$ & $60,70,80$ & $\begin{array}{c}3.5 \mathrm{Al}+0.2 \\
\mathrm{Cu} / 0.3 \mathrm{Cu}\end{array}$ \\
\hline RPI-AF & $70,80,90$ & $\begin{array}{c}3.5 \mathrm{Al}+0.1 \\
\mathrm{Cu} / 0.2 \mathrm{Cu}\end{array}$ & $70,80,90$ & $\begin{array}{c}3.5 \mathrm{Al}+0.1 \\
\mathrm{Cu} / 0.2 \mathrm{Cu}\end{array}$ & $60,70,80$ & $\begin{array}{c}3.5 \mathrm{Al}+0.2 \\
\mathrm{Cu} / 0.3 \mathrm{Cu}\end{array}$ \\
\hline \multicolumn{7}{|l|}{ Obese patients } \\
\hline $\begin{array}{l}\text { Normal body- } \\
\text { weight male }\end{array}$ & $70,80,90$ & $\begin{array}{c}3.5 \mathrm{Al}+0.1 \\
\mathrm{Cu} / 0.2 \mathrm{Cu}\end{array}$ & $80,90,100$ & $\begin{array}{c}3.5 \mathrm{Al}+0.1 \\
\mathrm{Cu} / 0.2 \mathrm{Cu}\end{array}$ & $60,70,80$ & $\begin{array}{c}3.5 \mathrm{Al}+0.2 \\
\mathrm{Cu} / 0.3 \mathrm{Cu}\end{array}$ \\
\hline $\begin{array}{l}\text { Normal body- } \\
\text { weight female }\end{array}$ & $70,80,90$ & $\begin{array}{c}3.5 \mathrm{Al}+0.1 \\
\mathrm{Cu} / 0.2 \mathrm{Cu}\end{array}$ & $70,80,90$ & $\begin{array}{c}3.5 \mathrm{Al}+0.1 \\
\mathrm{Cu} / 0.2 \mathrm{Cu}\end{array}$ & $60,70,80$ & $\begin{array}{c}3.5 \mathrm{Al}+0.2 \\
\mathrm{Cu} / 0.3 \mathrm{Cu}\end{array}$ \\
\hline Over-weight male & $70,80,90$ & $\begin{array}{c}3.5 \mathrm{Al}+0.1 \\
\mathrm{Cu} / 0.2 \mathrm{Cu}\end{array}$ & $90,100,110$ & $\begin{array}{c}3.5 \mathrm{Al}+0.1 \\
\mathrm{Cu} / 0.2 \mathrm{Cu}\end{array}$ & $60,70,80$ & $\begin{array}{c}3.5 \mathrm{Al}+0.2 \\
\mathrm{Cu} / 0.3 \mathrm{Cu}\end{array}$ \\
\hline $\begin{array}{l}\text { Over-weight } \\
\text { female }\end{array}$ & $70,80,90$ & $\begin{array}{c}3.5 \mathrm{Al}+0.1 \\
\mathrm{Cu} / 0.2 \mathrm{Cu}\end{array}$ & $80,90,100$ & $\begin{array}{c}3.5 \mathrm{Al}+0.1 \\
\mathrm{Cu} / 0.2 \mathrm{Cu}\end{array}$ & $60,70,80$ & $\begin{array}{c}3.5 \mathrm{Al}+0.2 \\
\mathrm{Cu} / 0.3 \mathrm{Cu}\end{array}$ \\
\hline Obese level-I male & $70,80,90$ & $\begin{array}{c}3.5 \mathrm{Al}+0.1 \\
\mathrm{Cu} / 0.2 \mathrm{Cu}\end{array}$ & $\begin{array}{c}100,110 \\
120\end{array}$ & $\begin{array}{l}3.5 \mathrm{Al}+0 \\
\mathrm{Cu} / 0.1 \mathrm{Cu}\end{array}$ & $60,70,80$ & $\begin{array}{c}3.5 \mathrm{Al}+0.2 \\
\mathrm{Cu} / 0.3 \mathrm{Cu}\end{array}$ \\
\hline $\begin{array}{l}\text { Obese level-I } \\
\text { female }\end{array}$ & $70,80,90$ & $\begin{array}{c}3.5 \mathrm{Al}+0.1 \\
\mathrm{Cu} / 0.2 \mathrm{Cu}\end{array}$ & $90,100,110$ & $\begin{array}{c}3.5 \mathrm{Al}+0.1 \\
\mathrm{Cu} / 0.2 \mathrm{Cu}\end{array}$ & $60,70,80$ & $\begin{array}{c}3.5 \mathrm{Al}+0.2 \\
\mathrm{Cu} / 0.3 \mathrm{Cu}\end{array}$ \\
\hline $\begin{array}{l}\text { Obese level-II } \\
\text { male }\end{array}$ & $70,80,90$ & $\begin{array}{c}3.5 \mathrm{Al}+0.1 \\
\mathrm{Cu} / 0.2 \mathrm{Cu}\end{array}$ & $\begin{array}{c}100,110 \\
120\end{array}$ & $\begin{array}{l}3.5 \mathrm{Al}+0 \\
\mathrm{Cu} / 0.1 \mathrm{Cu}\end{array}$ & $60,70,80$ & $\begin{array}{c}3.5 \mathrm{Al}+0.2 \\
\mathrm{Cu} / 0.3 \mathrm{Cu}\end{array}$ \\
\hline $\begin{array}{l}\text { Obese level-II } \\
\text { female }\end{array}$ & $70,80,90$ & $\begin{array}{c}3.5 \mathrm{Al}+0.1 \\
\mathrm{Cu} / 0.2 \mathrm{Cu}\end{array}$ & $\begin{array}{c}100,110 \\
120\end{array}$ & $\begin{array}{l}3.5 \mathrm{Al}+0 \\
\mathrm{Cu} / 0.1 \mathrm{Cu}\end{array}$ & $60,70,80$ & $\begin{array}{c}3.5 \mathrm{Al}+0.2 \\
\mathrm{Cu} / 0.3 \mathrm{Cu}\end{array}$ \\
\hline $\begin{array}{l}\text { Morbidly-Obese } \\
\text { male }\end{array}$ & $70,80,90$ & $\begin{array}{c}3.5 \mathrm{Al}+0.1 \\
\mathrm{Cu} / 0.2 \mathrm{Cu}\end{array}$ & $\begin{array}{c}100,110 \\
120\end{array}$ & $\begin{array}{l}3.5 \mathrm{Al}+0 \\
\mathrm{Cu} / 0.1 \mathrm{Cu}\end{array}$ & $60,70,80$ & $\begin{array}{c}3.5 \mathrm{Al}+0.2 \\
\mathrm{Cu} / 0.3 \mathrm{Cu}\end{array}$ \\
\hline $\begin{array}{c}\text { Morbidly-Obese } \\
\text { female }\end{array}$ & $70,80,90$ & $\begin{array}{c}3.5 \mathrm{Al}+0.1 \\
\mathrm{Cu} / 0.2 \mathrm{Cu}\end{array}$ & $\begin{array}{c}100,110 \\
120\end{array}$ & $\begin{array}{l}3.5 \mathrm{Al}+0 \\
\mathrm{Cu} / 0.1 \mathrm{Cu}\end{array}$ & $60,70,80$ & $\begin{array}{c}3.5 \mathrm{Al}+0.2 \\
\mathrm{Cu} / 0.3 \mathrm{Cu}\end{array}$ \\
\hline
\end{tabular}




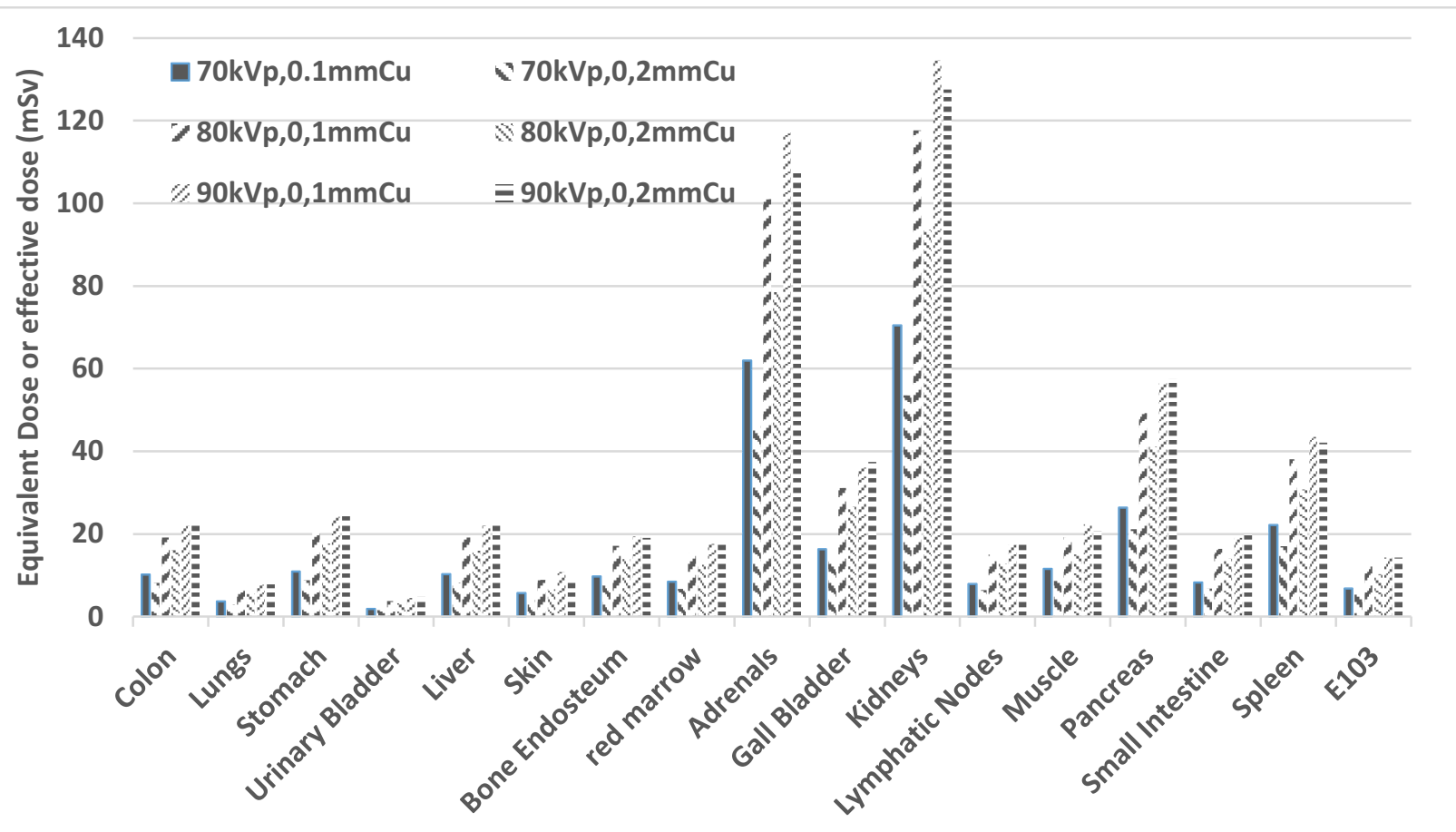

Figure 5. Comparison of organ dose data for different beam qualities.

$+0.1 \mathrm{~mm} \mathrm{Cu}$ are as almost two times high as those of 70 $\mathrm{kVp}+0.2 \mathrm{~mm} \mathrm{Cu}$.

This is mainly due to the fact that an increasing tube voltage can significantly enhance the beam energy while the increasing thickness of absorber would shield the low energy X-ray and thus reduce the X-ray intensity. The tube voltage determines the energy spectrum of the X-ray emitted from the source, the mean energy of X-ray emitted from source enhancing with increasing the tube voltage. The filtration impacts energy spectrum of X-ray reaching patient body, the mean energy of X-ray reaching patient also enhancing with increasing the thickness of filtration while the number of X-ray reaching patient body decreasing. Changing X-ray quantity can directly influence radiation -induced healthy effect of patient. Lower tube voltage and thicker filtrations should be employed at clinic to reduce patient's radiation risk as soon as possible.

\subsection{Comparison of organ dose data for different beam projections}

Figure 6 shows the results for different beam projections. The doses of adult male patients undergoing liver IR treatments with $90 \mathrm{kVp}+0.1 \mathrm{~mm} \mathrm{Cu}, 40 \mathrm{~cm} \times 40 \mathrm{~cm}$ FOV and six beam projections (PA, LAO, RAO, CRAN, LLAT and RLAT) were generated from VirtualDose-IR. Differences among the effective doses of all six projections are not far from each other, while some obvious divergences of organ doses among different projections have been found, especially for organs locating at the field.

The first reason is that the irradiation regions inside the body are not completely equivalent for each projection even the target positions are the same. Secondly, the attenuation distances for X-ray reaching internal organs change with beam projections. Couple with projections change, some parts of organs slightly move out the radiation field while other parts of organs move in, some organs are shielded by thicker tissues whereas others are shielded by thinner ones. The organs that distributed throughout the body are hardly impacted by these little field changes and receiving similar absorbed organ dose. Those reasons leading effective doses do not fluctuate tremendous following the projection changes.

Furthermore, the most significant divergences were observed for organ doses between LLAT and RLAT, especially for the asymmetric organs and tissues. Because shielding tissues thicknesses of these asymmetric organs and tissues can be changed dramatically with X-ray shifted to opposite side. In clinical operations, doctors can employ suitable beam projections to reduce doses for certain organ at risk. 


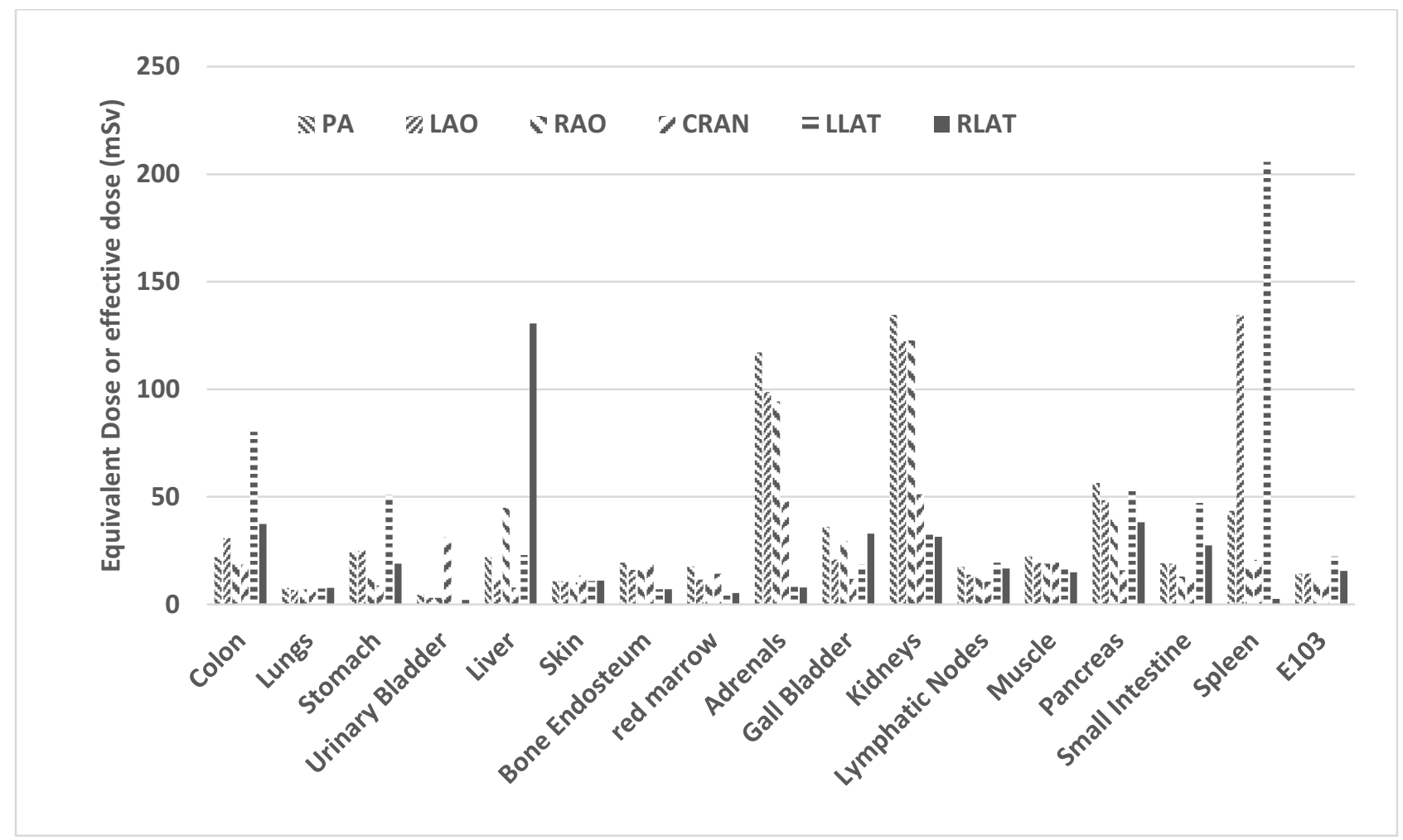

Figure 6. Comparison of organ dose data for different beam projections

\subsection{Comparison of organ dose data for patients with different ages}

A total of 4 liver IR treatments were independently performed on 5-year, 10-year, 15-year and adult male patients with the same conditions $(70 \mathrm{kVp}+0.2 \mathrm{~mm} \mathrm{Cu}$ beam quality, $40 \mathrm{~cm} \times 40 \mathrm{~cm}$ FOV, PA beam projection). The results were summarized in figure 7 . The effective doses and organ doses increase tremendously with age decreasing under this IR condition. Moreover, all the organ doses of 5-year male are much larger than others.

This is because the small size of paediatric patients will lead more organs and tissues to receive direct irradiations. Organs irradiated directly will receive far more radiation doses than organs which outside the irradiation region, because only a little parts of X-ray are scattered out the irradiation region. Moreover, the body sizes of young children also get smaller with age decreasing. Lacking other tissue shielding, the inner organs in a small body will receive more radiation dose.

As the adolescent are more sensitive to radiation rather than adult, especially for young children, the radiation doses for adolescence IR operations should be particularly concerned. The tube voltages performed in children IR treatments need to be set lower and filtrations employed need to be set thicker than adult treatments according to patient's age and body size.

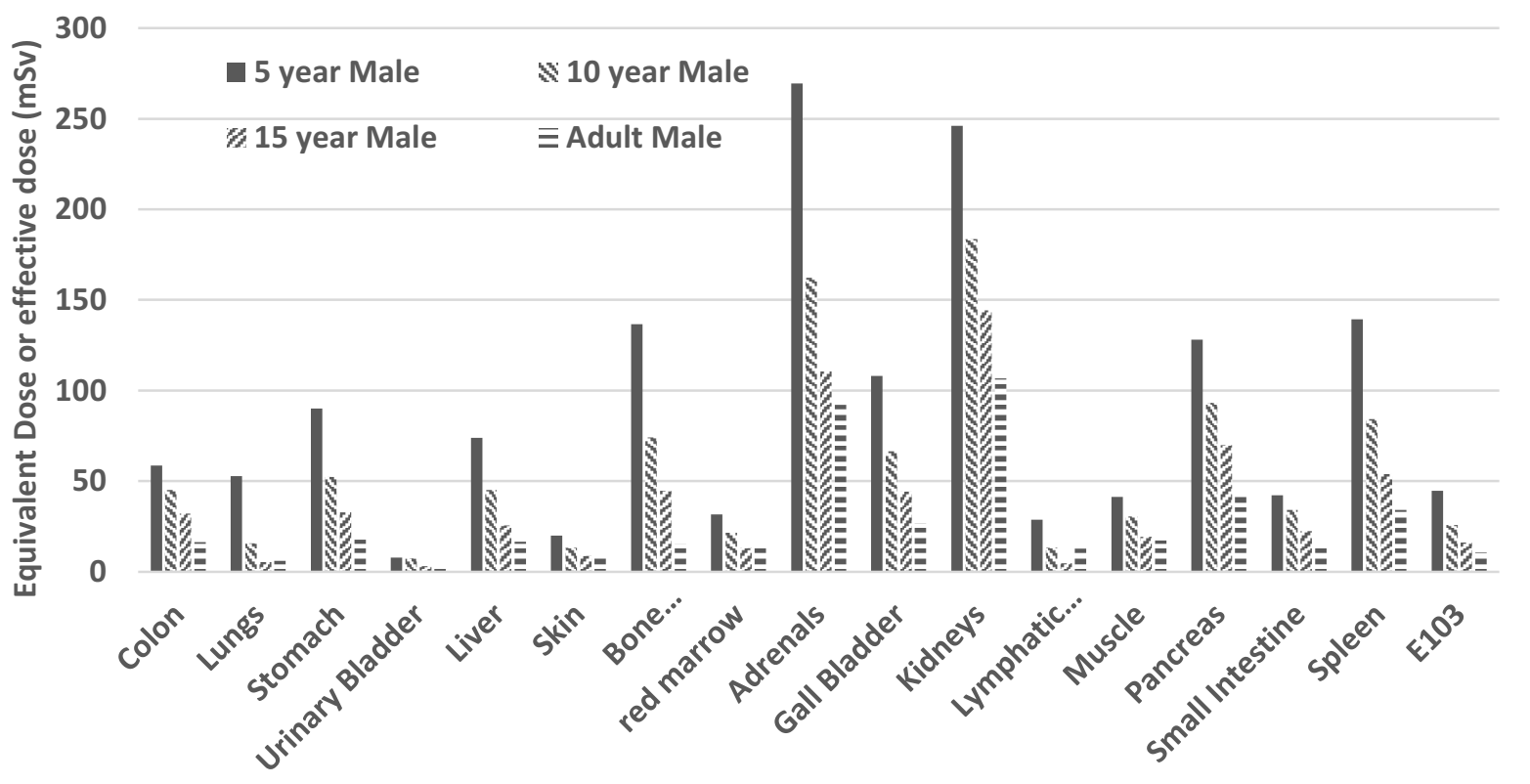

Figure 7. Comparison of organ dose data for patients with different ages 


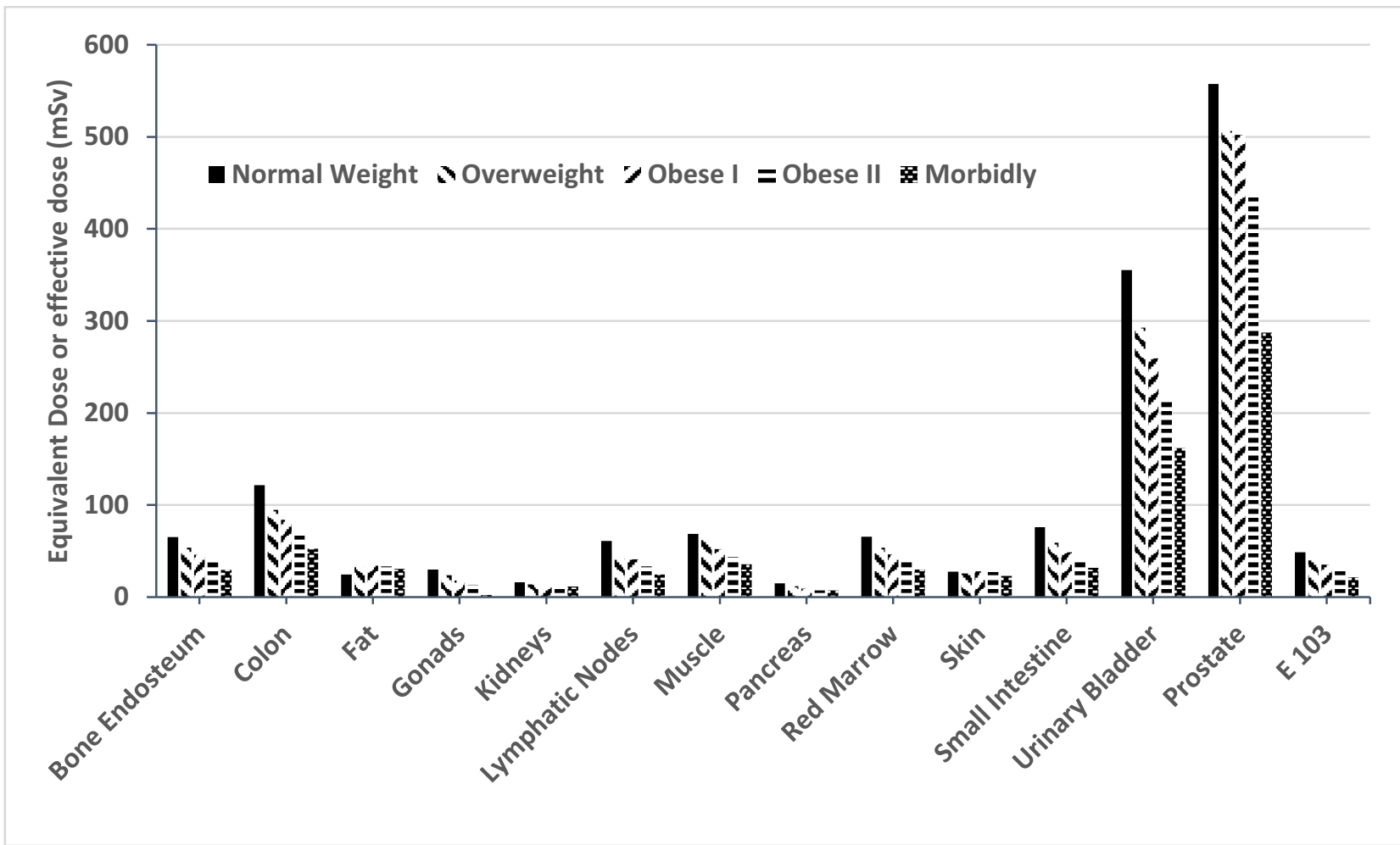

Figure 8. Comparison of organ dose data for patients with different BMIs

\subsection{Comparison of organ dose data for patients with different BMIs}

A small intestine IR treatment with $100 \mathrm{kVp}+0.1 \mathrm{~mm} \mathrm{Cu}$ tube voltage, $40 \mathrm{~cm} \times 40 \mathrm{~cm}$ FOV and PA beam projection was independently performed on 5 male patients with different obesity ( Normal weight, Over weight, Obese I, Obese II and Morbidly). Figure 8 shows that all the organ doses and effective doses are reducing with the enhancing of BMI. The morbidly obese patients receive minimum radiation doses compared to other type of patients in the same IR condition. Although on account of the effect that visceral fat occupies the original locations of some internal organs and changes their positions, the locations of those organs are not identical in those phantom. It still demonstrate the fact that BMI have great impact on doses of patient for an abdominal IR procedure.

These discrepancies are attributed to the fact that the abdominal fat has a great shielding effect against X-ray for internal organs. The abdominal fat is the major factor contributing to BMI increasing and has a great influence on body size, which will result in less radiation damage appear at obese patient compare with average adult and children.

But this shielding effect usually reduces image quality, so doctors need to enhance beam energy and intensity to get satisfied images during clinical operations. This result reveals that the BMI can impact patient doses and image quality markedly. Doctors are supposed to choose different IR plans for patient with different BMIs.

\section{Conclusion}

Based on a family of 23 anatomically realistic patient phantoms of both genders and various ages, organ dose database for the development of the VirtualDose-IR software has been reported successfully. The X-ray quality, beam projection, patient's age, patient's BMI and irradiation position have great influence on radiation dose of patients. When compared with previous researches, this database is found to be more suitable and flexible to evaluate radiation doses of patients in IR procedures because more IR parameters and irradiation positions were considered. Complying to the ALARA (As Low As Reasonably Achievable) principle in IR treatments, it is necessary to reduce the risk from the IR radiation exposure and optimize the medical benefit of IR procedures to patients. Clinical staffs can access to this database though VirtualDose-IR software to estimate radiation damage of patient before IR operation.

\section{Acknowledgment}

This project was supported in part by the National Institute of Biomedical Imaging and Bioengineering (NIBIB) (1R42EB010404). And by National Natural Science Foundation of China (Grant No. 11375182).

\section{References}

1. A. Ding, Y. Gao, H. Liu, P. F. Caracappa, D. J. Long, W. E. Bolch, B. Liu, X. G. Xu, PHYS. MED. BIOL 60, 5601-5625 (2015)

2. A. Ding, J Gu, P. F. Caracappa, X. Xu, MED. PHYS 37, 3463-3463 (2010)

3. A. Ding, Y. Gao, P. F. Caracappa, B. Liu, X. Xu, 
MED. PHYS 39, 3876-3877 (2012)

4. A. Ding, J Gu, M. Mille, X. Xu, B. Liu, J NUCL MED 51, 520-520 (2010)

5. B. Liang, Y. Gao, Z. Chen, X. G. Xu, RADIAT. PROT. DOSIM , 1-10 (2016)

6. A. Ding, Y. Gao, H. Liu, P. F. Caracappa, D. J. Long, W. E. Bolch, B. Liu, M. Kalra, X. G. Xu, MED. PHYS 40, 458-458 (2013)

7. A. P. Ding, Development of a radiation dose reporting software for X-ray computed tomography $(C T)(\mathrm{PhD}$ Thesis Rensselaer Polytechnic Institute, 2012)

8. A. P. Ding, J. W. Gu, A. V. Trofimov, X. G. Xu, Med. Phys. 37 6199-6204 (2010)

9. J. Gu, B. Bednarz, P. F. Caracappa, X. G. Xu, Phys. Med. Biol. 54 2699-2717 (2009)

10. J. W. Gu, X. G. Xu, P. F. Caracappa, B. Liu, Radiat. Prot. Dosim. 155 64-72 (2013)

11. H. Liu, Y. Gao, A. Ding, P. F. Caracappa, X. G. Xu, Radiat. Prot. Dosim. 164 368-375 (2015)

12. H. Liu, J. Gu, P. F. Caracappa, X. G. Xu, Phys. Med. Biol. 55 1441-1451 (2010)

13. P. F. Caracappa, J. Gu, X. G. Xu, Med. Phys. 373100 (2010)

14. D. A. Schauer, O. W. Linton, HEALTH. PHYS 97, 15 (2009)

15. US Food and Drug Administration. Initiative to reduce unnecessary radiation exposure from medical imaging (FDA, US, 2010)

16. F. A. Stewart, A. V. Akleyev, M. Hauer-Jensen, J. H. Hendry, N. J. Kleiman, T. J. MacVittie, B. M. Aleman, A. B. Edgar, K. Mabuchi, C. R. Muirhead, R. E. Shore, W. H. Wallace, Annals of the ICRP 41, 1-322 (2012)

17. J. C. Waite, M. Fitzgerald, RADIAT. PROT. DOSIM, 94, 89-92 (2001)

18. C. Theodorakou, J. A. Horrocks, BRIT. J. RADIOL, 76, 546-552 (2014)

19. K. Chugh, P, D. R. Bednarek, D. Wobschall, S. Rudin, K. Hoffmann, R. Peterson, M. Zeng, Medical Imaging 2004 Conference 5367, 464-473 (2004)

20. Y. Khodadadegan, M. Zhang, W. Pavlicek, R. G. Paden, B. Chong, B. A. Schueler, K. A. Fetterly, S. G. Langer, T. Wu, J. DIGIT. IMAGING 24, 626-639 (2011)

21. P. B. Johnson, D. Borrego, S. Balter, K. Johnson, D. Siragusa, W. E. Bolch, MED. PHYS 38, 5490-5499 (2011)

22. R. Kramer, H. J. Khoury, J. W. Vieira, PHYS. MED. BIOL 53, 6437-6459 (2008)

23. A. Bozkurt, D. Bor, PHYS. MED. BIOL 52, 317-330 (2007)

24. W. J. Garzón, R. Kramer, H. J. Khoury, V. S. M. D. Barros, G. Andrade, J. RADIOL. PROT 35, 629-647 (2015)

25. ICRP, The 2007 Recommendations of the International Commission on Radiological Protection (Oxford: Pergamon, 2007)

26. J. Zhang, Y. H. Na, P. F. Caracappa, X. G. Xu, Phys. Med. Biol. 54 5885-5908 (2009)

27. X. G. Xu, V. Taranenko, J, Zhang, C. Shi, Phys. Med. Biol. 52 7023-7044 (2007)
28. X. G. Xu, K. F. Eckerman, Handbook of Anatomical Models for Radiation Dosimetry (Boca Raton, FL: CRC/Taylor and Francis Group, 2009)

29. X. G. Xu, Phys. Med. Biol. 59 R233-302 (2014)

30. A. P. Ding, M. M. Mille, T. Y. Liu, P. F. Caracappa, X. G. Xu, Phys. Med. Biol. 57 2441-2459 (2012)

31. Y. H. Na, B. Zhang, J. Zhang, P. F. Caracappa, X. G. Xu, Phys. Med. Biol. 55 3789-3811

32. Y. Pi, M. Feng, W. Huo, L. Zhang, T. Liu, H. Lin, L. Yang, F. Zheng, H. Tan, F. Pan , Z. Chen, X. G. Xu, 5th International workshop om computational human phantoms, (2015)

33. M. Feng, A. Ding, Y. Gao, Z. Chen, X. G. Xu, 5th International workshop om computational human phantoms, (2015)

34. W. Huo, Y. Wang, X. Zhuang, Y. Pi, Z. Chen, X. G. $\mathrm{Xu}$, 5th International workshop om computational human phantoms, (2015)

35. Ministry of Health, The People's Republic of China, Dose conversion coefficients for use in radiological protection against photon external radiation (The People's Republic of China National Standard of Occupation Health, 2002)

36. D. B. Pelowitz, MCNPX User's Manual Version 2.7.0 (LLNL, Los Alamos, 2011)

37. C. Koukorava, J. Farah, L. Struelens, I Clariand, L. Donadille, F. Vanhavere, P. Dimitriou, J. Radiat. Prot. 34 509-528 (2014)

38. E. Carinou, P. Ferrari, C.Koukorava, S. Krim, L. Struelens, Radiat. Prot. Dosim 144, $492-496$ (2011)

39. AAPM, Functionality and Operation of Fluoroscopic Automatic Brightness Control/Automatic Dose Rate Control Logic in Modern Cardiovascular and Interventional Angiography Systems (The American Association of Physicists in Medicine, 2012) 